\title{
Evolution of Personnel Management in Colleges and Universities to Strategic Human Resources Management and Ways to Realization
}

\author{
Xiaojun Dai \\ Human Resources Office, Nanjing Forest Police College, Nanjing 210023, China \\ daixj@nfpc.edu.cn
}

Keywords: Personnel Management, colleges and universities, human resources, strategic management.

\begin{abstract}
With the development of information technology and economic globalization, the talent competition is increasingly fierce. Traditional personnel management in colleges and universities can no longer meet the needs of the development of the situation and must be changed to strategic human resources management. This paper applies the theory of strategic human resources management to the practice of personnel management in colleges and universities by using the methods of literature, expert interviews, questionnaire and so on, and probes into the ways to realize the strategic human resources management in colleges and universities.
\end{abstract}

\section{Introduction}

Colleges and universities undertake important historical missions in implementing the strategy of rejuvenating the country through science and education as well as in promoting social and economic development in our country. With the development of information technology and economic globalization, the talent competition is increasingly fierce and traditional personnel management in colleges and universities cannot meet the needs of the development of the situation. Colleges and universities must strengthen the development and management of human resources, take the development strategy of the state and the university as the starting point for the development and management of human resources, change ideas, perfect mechanisms, build teams, create environment, and actively promote the management of strategic human resources in order to win the first opportunity in the increasingly fierce talent competition.

\section{Evolution and Development Trend of Personnel Management in Colleges and Universities}

\subsection{Traditional Personnel Management Stage}

Traditional personnel management in China's colleges and universities has been under the planned economic system for a long time. The management of people is based on labor and personnel management and lacks close contact with the university's development strategy. The scope of traditional personnel clerk's responsibilities is relatively small, mainly including procedural document processing, as well as the establishment of specific systems and transactional management in personnel recruitment, selection, training, salary distribution, promotion of professional title, assessment, personnel file keeping, etc. The personnel management at this stage has the characteristics of passive, directive and routine. The personnel department has a low position in the university, and the staff can meet the needs of the work without professional training.

\subsection{Human Resource Management Stage}

With the increasingly fierce talent ccompetition and the rapid development of China's market economy, many colleges and universities have begun to pay attention to the management and development of human resources. The functions of personnel departments in colleges and universities are gradually expanding and their status is also gradually improving. The main work functions include the formulation of personnel policies in the university, recruitment and 
management of personnel according to the university's employment needs, and participation in the implementation of the university's strategic plan [1]. Personnel cadres have begun to enjoy more right to speak at the university decision-making level, which puts forward higher requirements on the quality and ability of the staff. However, in the process of forming the university's strategic goals, human resources have not received enough attention and cannot be regarded as strategic resources. The work of human resources departments is also often in a relatively passive state.

\subsection{Strategic Human Resource Management Stage}

At this stage, the development of human resources has become the key to the core competitiveness of colleges and universities. The human resources department has become the maker and promoter of the current strategy from the passive receiver of the previous college strategy. Colleges and universities begin to formulate specific human resources activities to achieve the strategic goals, and at the same time link human resources management with the university's strategic goals so as to improve the performance of employees and organizations. Human resources management is no longer limited to the responsibilities of human resources management departments [2]. University managers at all levels need to assume corresponding responsibilities. The quality requirements for staff members are getting higher and higher. They should not only have correct concepts, modern human resources management knowledge and technology, but also have the core competence of strategic management.

At present, most colleges and universities in our country are still in the stage of transition from traditional personnel management to strategic human resources management. The personnel management department of colleges and universities is generally the personnel department, which is the specific administrative functional department and is responsible for organizing personnel deployment, assessment, training, personnel files, management and formulation of labor standards, etc. The most urgent task for colleges and universities is to change from traditional personnel management and human resources management to strategic human resources management as soon as possible. The human resources department should not only be an administrative department, but also be a research and development department. It should have sufficient human resources for the development of universitys. Human resource is kind of capital, so human capital must be developed and effectively managed. Colleges and universities are places where talents gather, so they should establish real human resources management departments to give full play to their role and guide the planning and development of teaching staff in their personal career while ensuring the development of colleges and universities. Colleges and universities must regard human resources as the most precious strategic resources. Through scientific planning, development and management of human resources, they can serve the strategic objectives of colleges and universities and strive to form their own core competitive ability so as to obtain sustainable competitive advantages.

\section{Connotation and Characteristics of Strategic Human Resources Management in Colleges and Universities}

In the era of knowledge economy, human resources have become the first resource and also the most active, precious and vital resource. Under this background, strategic human resource management comes into being. The application of the concept of strategic human resource management appeared in the early 1980s. For example, Kanter (1983), Baird and Mesholam ( 1988 ) believe that organizations need a strategic human resource management process to help them cope with the needs of flexibility and innovation. Strategic human resources management is the further development and perfection of traditional personnel management and human resources management. It is the inevitable result by the continuously rising importance of human resources in the organization and the interaction of internal and external factors such as economic globalization and the era of knowledge economy. It embodies the strategic thought of "people-oriented, core talentsoriented, and the common development of individuals and organizations", and represents the new trend of human resources management development.

Strategic human resource management, also known as SHRM, is a human resource management 
mode based on the overall development strategy of the organization. The strategic human resource management in colleges and universities is a human resource management mode based on the overall development strategy of the university, with the research, formulation, planning and implementation of the talent strategy that conforms to the long-term goals of the university as its core. Its fundamental task is to improve the performance of teams and individuals that conform to the strategic goals of the university [3]. It is the historical necessity that human resource management in colleges and universities replaces personnel management and finally moves towards strategic human resource management.

Compared with traditional personnel management and human resources management, the strategic human resources management in colleges and universities has the following characteristics:

\subsection{Strategical}

The talent resources possessed by colleges and universities are the decisive resources for obtaining competitive advantages. Among them, core talents are indispensable to the implementation of university strategy. The development and management of core talent resources are the key to the formation of the university's core competitiveness and the realization of its strategic goals.

\subsection{Systematic}

Human resource management policies, practices, methods and means deployed by colleges and universities in order to obtain sustainable competitive advantages constitute a strategic system.

\subsection{Fitful}

It covers vertical fit, that is, human resources management being in line with the strategies of colleges and universities, and horizontal fit, that is, the fit between the various components or elements of the entire human resources management system.

\subsection{Goal-orientated}

The basic task of strategic human resources management in colleges and universities is to help colleges and universities create higher values and ensure to obtain sustainable competitive advantages through effective human resources management and development, especially the development of core talents' creativity.

\section{Ways to Realize Strategic Human Resource Management in Colleges and Universities}

\subsection{Realize Transformation of Strategic, Market-oriented, Decentralized and Integrated Human Resource Management from the Perspective of Concept}

\subsubsection{Strategical target}

Managers should take the realization of the national and university's development strategic goals as the starting point for human resource allocation, management and development, and regard the medium-and long-term human resource planning as the primary link. They should take a broad view on the domestic and foreign competition focus, track the development trend of domestic and foreign universities, focus on the formation of the overall competitive advantage of the university, and organize human resource development and management activities from a strategic perspective.

\subsubsection{Marketization of allocation}

Managers should establish a human resources management system that conforms to the principles of market efficiency and fairness, complies with the development rules of modern universities, and meets the development requirements of the times. It should be guided by market mechanisms and allocate human resources and development resources through multiple channels. The concepts of efficiency, competition and mobility should be developed [4]. Through the implementation of personnel management methods such as personnel agency and personnel 
dispatch, personnel relationship management and personnel use in colleges and universities are promoted to divide the management from the uses, and the marketization of personnel resource allocation, the contractual use of personnel, as well as the socialization of service guarantee can gradually be realized.

\subsubsection{Decentralized management}

The routine work function in the process of strategic human resources management in colleges and universities will be transferred to the level of departments and colleges. Departments and colleges will enjoy more autonomy. The gradual establishment of a secondary management system of personnel resources planning, control, supervision and independent implementation in departments and colleges will make the human resources management activities of the whole university more open and more directly face the competitive environment. The faculty should be given the power to employ teachers and the power to gain post salaries, in order to give full play to the enthusiasm and important role of the faculty in personnel system reform as well as strategic human resources management [5]. At the same time, the university should strengthen the supervision and management of the faculty through the establishment of supervision, guarantee, binding mechanisms such as the implementation of accountability system and the lowliest place elimination series in the discipline.

\subsubsection{Integrated coordination}

In order to realize the university's development strategy to the greatest extent, all aspects of human resources allocation should be coordinated organically; systematic management should be carried out; synergy should be pursued, and a convenient, efficient and internally unified strategic human resources management system should be gradually established.

\subsection{Establish and Perfect a New Mechanism for Human Resources Management and Development based on the theory of Strategic Human Resources Management}

First, a multi-level personnel recruitment mechanism should be established. On the one hand, it is necessary to strengthen the introduction of high-level core talents. High-level talent resources are strategic resources to ensure the realization of the university's development strategy and obtain competitive advantages. Discipline construction should be the leading factor; teaching and scientific research should be the dual axis; personnel allocation should be carried out; proactive, internationalized and institutionalized talent introduction strategy should be implemented; field directors should be brought together with great efforts and capital to promote the introduction of core talents and teams. On the other hand, it is necessary to "do something and not do something". the employment of personnel should be managed by classification and level, and the main focus should be put on the development and management of mainstream teams and high-level core human resources. In order to realize the university's talent development strategy, the human resources management and development work in colleges and universities should focus on the teaching and administrative staff with high academic qualifications, high professional titles and decisive role in the university's development strategy, and pose relatively low demands on the teaching and administrative staff with low academic qualifications and low professional titles. Through the implementation of personnel agency and personnel dispatch, personnel relations and personnel use can be gradually separated. Only in this way can the university focus on the important work directly related to the university's strategic development, such as the introduction of high-level personnel, the employment of teachers, the strengthening of job management, and the performance evaluation of teaching staff.

Second, the post appointment mechanism should be launched. Colleges and universities should deepen the reform of human resources allocation with post management as the core, and with post employment and employment contract management as the basic characteristics, so as to achieve appropriate and reasonable allocation of employees and posts, which ensures that the overall strategy of the university is consistent with the human resources strategy, and realizes the optimization of human resources allocation. Post appointment system is the core content of 
personnel system reform in colleges and universities. It is the focus of strategic human resources management in colleges and universities. The employment of teachers and scientific research personnel as well as the employment of Party and government management personnel should be of "two-track linkage" [6]. On the one hand, the separation of evaluation and employment of teachers' positions should be implemented. Only in this way can "weakening identity management and strengthening position management" truly be implemented, so that the shortcomings of seniority be overcome, and outstanding young people can have the opportunity to stand out. On the other hand, the education system for party and government management personnel will be implemented to terminate the evaluation and appointment of professional titles for party and government management personnel, so that the management work in colleges and universities will develop in a professional direction.

Third, a strategy-oriented performance evaluation mechanism should be established. As an important core content of the human resources management system in colleges and universities, performance evaluation should be the transmission system of the overall development strategy of the university. Through a scientific and reasonable performance evaluation system, the university's development strategic thoughts, goals and core values should be transmitted to all teaching and administrative staff layer by layer so as to encourage them to make efforts to realize the strategic goals of the university. Through reasonable strategic human resources management, the university's goals should match the personal development goals of teaching staff as much as possible, to achieve the university's development strategic goals and the personal development goals of teachers at the same time to a certain extent. The formulation of scientific and reasonable evaluation methods plays an important role in strengthening post management, arousing the enthusiasm of teaching staff and improving the competitive incentive mechanism. The evaluation method should follow the law of academic research and provide sufficient development space for talents who "spend ten years working on their filed". At the same time, the relationship between qualitative and quantitative, quantity and quality, short-term effect and long-term effect, and the role of individuals and teams should be well handled.

Fourth, a competitive incentive mechanism for strategic talents should be established. The incentive system includes personal incentive and team incentive, which is the direct power source for the construction of high-level core talents in colleges and universities. The implementation of various incentive methods must have a clear strategic orientation and must strengthen the incentive function. Under the principle of "giving priority to efficiency and giving consideration to fairness", managers should establish a distribution and incentive mechanism that focuses on achievements and contributions and favors high-level talents as well as key positions, so as to attract talents, stabilize the contingent, and mobilize the enthusiasm of the vast number of teachers to achieve high performance, which is conducive to the development of the university.

Fifth, a mechanism for training and developing strategic human resources should be established. To train the faculty is an important means to improve the quality and innovative ability of the talents in colleges and universities, to construct the strategic reserve of talents, and to enhance the university's competitive ability. The university should focus on the needs of long-term strategic development, perfect the training and development mechanism for teaching and administrative staff, create a team of young and middle-aged academic backbones and leaders in their chosen fields of learning with innovative spirit and development potential, continuously optimize the structure of teaching and administrative staff and improve the overall quality.

\subsection{Establishing a High-quality Strategic Human Resources Management Team}

The strategic human resources management department in colleges and universities is not only the daily human resources management department, but also the human resources research and development department. Therefore, higher requirements should be put forward for the human resources management staff in colleges and universities. The object and environment that human resource management faces are changing all the time. The corresponding human resource management concepts, methods and means must be changed and adjusted in a timely manner. 
Human resource managers in colleges and universities should have the knowledge and skills of modern human resource development and management, including the basic theories of modern human resource development and management, personnel psychology, sociology, behavior, pedagogy, etc, and basic technology and practical skills engaged in human resources planning, recruitment, training, development, performance evaluation, salary design, incentive and other specific human resources management activities. They should have the core capabilities of strategic management, including three core capabilities--insight, adaptability and control. They must try their best to cultivate and improve their ability to fully grasp the overall situation, internal and external environment and changing trend of human resources development in the university.

In addition, strategic human resources management is not only the responsibility of personnel management departments, but also the important responsibility of all management personnel including the principal, it is necessary to strengthen the training and guidance of human resources management personnel.

\subsection{Creating a Good Working Atmosphere and Environment}

An U.S. management expert Koontz pointed out: "Management is to design and maintain a good environment so that people can efficiently accomplish the set goals in groups.” It is the same with the strategic human resources management in colleges and universities. It is necessary to emphasize the "people-oriented" management, create a good working atmosphere and environment for the teaching staff, pay attention to the protection of the rights and interests of the teaching staff, and respect the personal development of teachers as well as the shaping of the corresponding campus culture. They should integrate, cultivate and develop the core culture of the university, integrate the culture into the practice of attracting, cultivating, developing and retaining outstanding talent resources, practice the strategic thought of "unity of people and university; common development" and create an environment that encourages employees. In this way, it can promote the employees' potential, creativity and enthusiasm, and create conditions for outstanding talents to stand out.

\section{Conclusion}

Traditional personnel management in colleges and universities can no longer meet the needs of the development of the situation and must be changed to strategic human resources management. This paper applies the theory of strategic human resources management to the practice of personnel management in colleges and universities by using the methods of literature, expert interviews, questionnaire and so on, and probes into the ways to realize the strategic human resources management in colleges and universities.

\section{References}

[1] PANG Hongmei, QIU Ailian. (2017) People-oriented Management: the New Knowledge in the Development of University Informatization. Modern Education Management, 11, 56-61.

[2] Zhang Lina,Xia Qingli. (2016) The Realistic Dilemma and Countermeasure of Human Resource Management in Colleges and Universities. Academic Forum, 4, 156-161.

[3] SHEN Yong. (2016) Logic and Route of Faculty Participation in Institutional Personnel Reform. Journal of Higher Education Management, 12, 113-117.

[4] Yin Yuqi. (2015) University Charter and legalization of personnel management in Colleges and Universities. Jiangsu Higher Education, 4, 44-46.

[5] Guan Peijun. (2015) On the direction and strategy of personnel reform in Colleges and Universities. Peking University Education Review, 1, 179-187.

[6] ZHANG Fan, WEI Xueli, CAI Feng. (2016) Study on Humanization of University Management from the Knowledge Management Perspective. Modern Education Management, 8, 15-19. 